\title{
SCIENTIFIC SUBSTANTIATION: FOR AND AGAINST 6-YEAR-OLD CHILDREN COMMENCING SCHOOL EDUCATION
}

\author{
Anna Liduma \\ University of Latvia, Latvia
}

\begin{abstract}
The scientific article actualizes the pedagogical process at preschool. It actuates school year 2017/2018 pedagogical process for Latvia state's needs and involves education (teaching and learning) and upbringing/self-upbringing (attitudes' development to oneself, others, nature, work, culture, state and society). The assessment is provided for the open to debate Project No 8.3.1.1/16/I/002 "School 2030 Competence approach to education content" as the scientifically non-substantiated content, which makes provision only for education. The scientific substantiation of the article is based on the child development in early childhood (0-8 years) actual theories by A. Spona, A. Liduma, Latvian scientists, G. Craig \& Baucum, the USA psychologists, and A. Rean, Russian psychologist. Analysis of the Content of Preschool education of the year 2012 by Latvian Ministry of Education and Science and the Cabinet of Ministers. The empirical research analyses different visions on the 6-year-olds' maturity/readiness for school by the deputy head-masters in education at preschool education establishments of Latvia's regions. The opinions for and against the 6year-olds' education at school by children parents and the preschool pedagogy students have been analysed.
\end{abstract}

Keywords: preschool pedagogical process, six-year-old child development and education at school.

\section{Introduction}

In Latvia the preschool pedagogical process is organized in accordance with the CM regulations No 533 Regulations on the state education guidelines developed by the Ministry of Education and Science (MES) and the Cabinet of Ministers (CM) and affirmed on $31^{\text {st }}$ July in 2012. In compliance with the state needs of Latvia, at preschool children all-round (physical, psychic, social) and harmonious (intellectual, emotional, volition) development are promoted, taking into consideration the child's psychic process development regularities and the child's actual needs. The needed knowledge, skills and attitudes for individual and social life are promoted, successive and purposeful preparation for the acquisition of basic education is ensured. CM regulations become effective on $17^{\text {th }}$ August in 2012 (Regulations of the State preschool education guidelines, 2012). These regulations are still in force in the school year of 2017/2018.

(C) Rēzeknes Tehnologiju akadèmija, 2018 http://dx.doi.org/10.17770/sie2018vol1.3377 
Browsing on the recently accessible materials for the national debate "School 2030 Competence approach to education content" (Project No 8.3.1.1/16/I/002), it has been established that in future the pedagogical process is not being planned, but only education given at preschool. Such a cardinal opposition at the state level to up to the present relevant pedagogical process (education and upbringing) work organization at preschool, spotlights the question on the national/state usefulness of this project, because of: 1) the nationally significant needs of Latvia are not observed by it - the upbringing is absolutely eliminated; 2) devoid of a scientific substantiation in accordance with the needs of the state of Latvia provided by Latvian pedagogy and psychology scientists; 3) problematic is the attitude of this project developers to the values important for the Latvian state, as up to present the upbringing has been the greatest value as a significant and important constituent part/component of the pedagogical process. 4) to date it serves as the main constituent part/component for passing of culture values and work organization at preschool age, which is in compliance with the development aetiological regularities in preschool age children: development by observation and following the model. If the values important for Latvia are not developed by upbringing, then such an attitude has to be considered as detrimental, which constitutes a menace to the state of Latvia.

The above mentioned arguments stimulated the analysis actualization of 6year-old children development scientific substantiation in the preschool pedagogical process.

The theoretical substantiation of the article is gained via the processional structural methodological approach by pedagogy scientist A. Spona (2006) and the action approach based on A. Liduma's conceptions on the pedagogical process $(2013,2014)$ and collaboration (2017) at preschool, G. Craig \& D. Baucum (Craig \& Baucum, 2004), A. Rean's (Реан, 2006) psychological child in the early childhood (0-8 years) development substantiation.

The following theoretical methods have been implemented during the research: the scientific literature analysis and the content analysis of the MSE and CM documents and empirical methods: pedagogical observations, preschool teachers interviews (various regions), Riga preschool education methodologists' interviews, questions and answers by the pedagogy students in preschool and school pedagogy in different regions of Latvia and Riga city, interviews with parents.

The research involved 500 respondents. 


\section{The theoretical essence of the pedagogical process for six-year-old children}

The human's all-round/holistic development entirety is determined by the psychic structure, which is constructed by 3 reciprocally interconnected components: 1) psychic processes - cognitive processes, attention, emotions, volition; 2) personality features - abilities, interests, temperament and character; 3) self-experience, attitudes and skills.

According to N. Gage and D. Berliner's explanation „feature or trait is manifested by a long-term personal behaviour, which is influenced by conditions and situations” (Geidžs \& Berliners, 1999: 133).

The personality development increases the creative action development, and vice versa, the high level of the creative action characterizes a more advanced development of the personality (Hibnere, 1998: 20). She has accentuated that the creative personality, who is a human of genuine culture, independent, autonomous, possessing initiative, socially active, intellectual, with practical abilities, professionally competent and able to orientate oneself in art is especially significant and particularly in Arts pedagogy (Hibnere, 1998: 170).

By employing the holistic approach into work of the preschool pedagogue and by promotion of all-round (physical, psychic and social) and balanced psychic (intellectual, emotional and volition) development in the groups of $3-7$ years old children, at preschool education integrated sessions at the preschool of X Primary School during school year 2016./2017. by means of the pedagogical observation it has been established that the child, according to L. Vigotsky's (Выготский, 1997) conclusions, can employ action in two ways: 1) in the actual development zone autonomously, while 2) at the closest or proximal development zone - with the adult support, through a purposeful action gradually accumulating miscellaneous experiences and enriching cognitive interests, learns to self-assess and self-actuates new abilities.

Significant is the fact that at preschool the child's simultaneous perception and the abilities to accomplish an integrative action are developing: to listen to and accomplish a reproductive or creative activity simultaneously.

As the founder (in 2009) and board member, the author has had opportunities to observe Latvia's Preschool music education association actions at the preschool pedagogue further education courses and conferences profoundly. Consequently, the author has accumulated sufficient absolute evidence that the preschool pedagogical process in Latvia is being organized purposefully. The all-round development is being promoted due to the personally significant action of the child. The teacher's position is a crucial condition in the development of the child's habits and self-regulatory attitude to the responsibilities and rights prescribed by the state legislation. By word and by model the teacher prepares the child for the action psychologically and promotes 
the comprehension of the task's personal significance for the child by using of an appropriate content and ways of work appropriate to the needs of the age.

While working with children at preschool and carrying out scientific researches, since 1987 the author of the article has been implementing the allround approach in the pedagogical process in practice. The dissertation was defended in 2004, since then the research in the child musicality development promotion possibilities has been continued by involving the anthropological approach (Wulf, 2007) into practice. The gained information has been included into the lectures of the upbringing theories and methodology for the Latvia and Erasmus students (Turkey, Portugal, Spain, the Czech Republic, Germany, Austria) during the academic years of 2012 - 2017 as well as has been involved into the author's lectures of the post-graduate students in Pedagogy, included into the further education courses in Pedagogy, as well as presented at the conferences of different international organizations all over the world. The experience of a participant has been gained at the documentation preparation for a transnational project on Teaching Common Values in Europe, which has been affirmed by the European Parliament in August 2017. Consequently, the European states have promoted the common values, which as a result are included into the pedagogical terminology (Veugelers, de Grot, \& Stolk, 2017).

At preschool, it is important to consider that all the child's abilities are developed and promoted through the action, which is based on the satisfaction of their needs. It commences with the need to cognize, information perception, observations, developing of representations, emotional world exploration amid supportive natural and material environment, in the family micro environment, continues at the preschool mezzo environment and gradually find complementary and increased development in the society macro environment, which stimulate and promote activity. At preschool, this process inevitably needs a massive support with scientifically substantiated purposeful play-sessions' content and an individual approach to the child's all-round development promotion in practice. Therefore, it is significant to implement the valid suggestions recovered in the regulation documents by the Ministry of Education and Science, into the pedagogical process dynamics' organization, hence, ensuring the children opportunities to promote their self-development at the preschool educational institutions.

The content of the preschool education programme has been developed in order to promote the children's preparation for school, with inclusion of the individuality development, intellectual (knowledge), physical (the body acknowledgement) and social (communication and collaboration skills) development, initiative, inquisitiveness, self-dependence (self-service and behaviour skills) and creative activity development, strengthened health and 
psychologically prepared for school (positive attitude to education). At preschool the pedagogical process (education and upbringing) is organized so that the children learn by means of playing (Noteikumi par..., 2012).

Noteworthy that the children have to acquire the Preschool education programme from the age of one year up to the age of seven years in accordance with the General Education Law (Section 20). The preschool education programme acquisition time period can be either prolonged up to one additional year, or the schooling can be commenced at the age of six years in accordance with the doctor's statement of the child's health condition and the psychologist's statement on the child's psychological readiness to start education at school.

This article accentuates how significant is the scientific substantiation of the pedagogical process. The National Centre for Education (VISC) pilot project research "Approbation of Introduction of the six-year-olds' education programme" piloted from the $1^{\text {st }}$ September in 2010 till the 30 $30^{\text {th }}$ May in 2011 at 22 educational institutions (12 preschool educational institutions and 10 schools) of Latvia has recently been accomplished and "The integrative education programme for six-year-old children" has been approbated. As a result, the methodological material and education aids for pedagogues, the programme for pedagogues' professional perfection courses, methodological recommendations for developing of reading and writing skills, as well as for the children education achievement assessment in all subjects have been developed.

The assessment of the results of the pilot project revealed that in majority the content of the integrative education programme is in accordance with the perception and abilities of six-year-old children. According to the results intended to achievement, $92.5 \%$ of the presented knowledge was attained by the learners, but $7.5 \%$ of the knowledge caused difficulties to them, $80 \%$ of the skills were acquired by the learners, but $20 \%$ were not acquired by the learners, $87.3 \%$ of attitudes were acquired by the learners, but $12.7 \%$ were not acquired by the learners due to the programme. The pilot research had revealed massive differences in the individual child development. Consequently, a conclusion was drawn that a part of the children are not ready to commence learning at school at the age of 6 years. Therefore, the mandatory demand to commence the schooling at the age of 6 years was not introduced, yet the children can commence the school attendance either at the age of 6 years or at the age of 7 years, or at the age of 8 years (Līduma, 2014a: 40).

\section{Importance of pedagogical process at preschool education}

The author of the article implements the pedagogical process of the preschool education according to the content of the programme developed by the Ministry of Education and Science and affirmed by the CM on the $31^{\text {st }}$ July 
in 2012, which enhances as its crucial task to promote the skills in children through action and prepare the children effectively for education at school. The guidelines predict the social, intellectual and physical preparedness level of the child appropriate before commencing education at school at the age of 7 years, as well as anticipate the promotion of the self-expression by the children. The preschool guidelines have enumerated the basic skills, which are recommended to be acquired by the children till the age of 6 years, namely: skill to collaborate, to speak, skill to listen to, to tell, to take care of oneself, to hear and perceive different sounds either in nature or in the words heard. In order to prepare the children for school attendance physically, it is important for the children to acquire the skills to orientate oneself in space, to run, to march, to keep balance. Thus, the integrative approach to the children development at preschool recommends to put into practice three important actualities at organizing of the play-session content:

1. The development of children is being promoted at the individual tempo, which depends on the child's birth time (spring or autumn), because the child's biological age and individual development are not always reciprocally connected.

2. The preparation of the children for education at school has to be implemented purposefully by observing the principle of successions from the easier to more challenging (three pioneers of pedagogy have introduced it into pedagogy in the $17^{\text {th }}$ century: Wolfgang Ratke (Germany, 1613), Francis Bacon (England, 1623) and Jan Amos Komensky (Comenius) (Czech Republic, 1632) (Pedagogical museum of J. A. Comenius in Prague, 2017; Špona, 2006).

3. The transition from the play-session to the learning action appears gradually, due to the adaptation of the children at the school environment for a few days (it is practised throughout Europe). Therefore, initially short learning tasks are included into the playsession, but the learning tasks included into the play-sessions at the end of the year are longer.

Such an approach promotes a contemporary preschool age children development, a well-considered performance of this process and the respective result according to the individual potential abilities of each child.

According to the programme any session content comprises 8 education content areas or an integrated content of education subjects: 1) the Latvian language (language developing and orientating in the surroundings, speech developing in the native language, giving of an insight into literature and folklore, developing of writing skill and reading skill); 2) nature science (language developing and orientating in the surroundings, sensory developing, 
actions with objects, giving of an insight into nature); 3) mathematics (sensory developing, constructing, developing of mathematical concepts, mathematics); 4) social knowledge and ethics (language developing and orientating in the surroundings, developing of social skills, activities with objects, giving of an insight into surroundings and social life procedures); 5) music; 6) physical education (developing of movements) and health; 7) visual art (sensory developing, activities with objects, sculpturing activities, drawing, painting, moulding); 8) domestic science and technologies (performing activities, housekeeping, handicraft, applique work, constructing) (Pirmsskolas Izglīīibas mācību satura programma, 2012: 4).

The school pedagogical process content in Latvia involves education (teaching and learning) and upbringing/self-upbringing (attitudes to oneself, other humans, work, nature, culture, society, state). It cannot be directly transferred to school, as the psychologists (Эльконин, 1989; Craig \& Baucum, 2004) have formulated that at the preschool age the leading action of the child is play, a plot role-play, moreover, the cognitive action (learning) is being accomplished through observations and then by modelling at role-playing action the observed through collaboration of the child-child, the teacher-child (Lìduma, 2013, Līduma, 2014a, Līduma, 2017).

According to the upbringing theory the attitudes develop as integrated personality features. There are distinguished situational, habitual and selfregulatory attitudes. The attitudes to oneself, others, nature, work, society and the state develop throughout the human's lifetime (Špona, 2006). The children gain knowledge and learn skills to use knowledge at the play-sessions (the teacher promotes, the children observe and model). The content of the both components (play-session action and upbringing) of the pedagogical process reciprocally interweaves and stimulates the children development. The child's identity and self-exploration are promoted through personally significant purposeful action. All psychic processes are developed. The abilities are being developed from the innate potentials through action (Liduma, 2013, 2014b, 2017).

As it is significant to refer to the experiences of other countries, then to this research valid are conceptions by J. Greata (2006), G. Craig (2004), A. Rean (2006), H. Gardner (2009) and Latvian scientists (Līduma, 2017; Hibnere, 1998); Špona, 2014; Stangaine, 2014; Vigule, 2014; Randoha, 2015) claiming that the child is creative since its very birth, therefore, it is important to support the child's creativity purposefully, because the child's autonomous creative action activates its psychic processes, causes and maintain positive emotions.

In accordance with J. Greata's findings the early childhood experiences (from the birth to the age of 8) have the decisive impact on children's lifelong learning and positively contribute to their health and further development. 
Therefore early childhood education programmes with the mark of quality benefit children with greater readiness for and success in school (Greata, 2006).

The project No 8.3.1.1/16/I/002 "Competence approach to education content" materials envisage that the approach to education will be transformed in order to attain the aim - to ensure each learner with access to contemporary competence education.

This document has explored the aims, main results to be reached by learners, mandatory education content, the approach to education and the organization of the education work at every stage of general education preschool, primary education and secondary education. National Centre for Education (VISC) has initiated into deep changes to approach to education in Latvia, in order to revise by means of a united system and successively at all stages of education, the education content and the way of educating to be organized and guided by teachers in collaboration for the routine learning of the learners.

It has been stressed that since the previous education content reform before ten years, the society has endured essential changes. Not only in Latvia, but also beyond Latvia it has been directed that the future society needs different skills than the ones developed by the traditional education systems. Therefore, knowledge and skills, which must be gained at school, undergo transformation so, that each child and the society on the whole is successful and competitive. Therefore, schools have to strive to such learning experiences, which result in the learner's competence or expertness proficiency - a synergy of knowledge, skills and willing and able for action, which is in due way based on values, personality's features and habits. Therefore, the most essential of the changes the content - is developed, interim thinking about the result to be reached by each learner, videlicet, the child learns knowledge, skills, attitudes at the respective age irrespective of its relocation in a particular education institution.

Here it has to be pointed out that from the document has disappeared the uniform pedagogical process, which consisted of two pedagogical process components: education is here, while the upbringing - is missing. Should the future human be devoid of upbringing?

By further researching of different opinions on the 6-year-old children education in school, a significant interview has been discovered. Irmeli Haninena, the emeritus leader at Finnish State agency for the education content development, while giving an interview to Ilze Kuzmina, answered the question why the six-year-old children do not learn in schools in Finland: "The six-yearolds do learn, yet it is at preschool preparatory education. They acquire essentials that will be needed at school. We believe that the six-year-olds are not mature for the school as such yet. The best age to begin systematic education is 
at the age of seven. We have concluded it due to the researches in brain and fine motorics' development at different age stages. The observations also prove that exactly at the age of seven years the children will have the utmost dexterity to acquire the skills of reading, writing and counting. A part of the children can read already before the beginning of their schooling, nevertheless, this skill is not mandatory. Some children possibly are ready for school earlier. In such cases, if the parents want, they can apply their child for entering the school earlier, however, before enrolling the tiny one into the school, it has the right to set test in order to establish if the child is mature enough to start learning" (Kuzmina, 2017: 5).

Answering the questions about the 6-year-old children education at school asked by Anete Bērtule, the correspondent of Latvia's Television, Ilze AbeliteGoluba, mother of three children and a preschool teacher tells that her four-yearold daughter will already have to start attending school in two years. Both of her youngest children will directly be triggered into the planned changes by the minister of Education, and, remembering her eldest son at the age of six, she categorically assesses that "it is not really possible to make a six-year-old take a place at the school-desk, because, if according to their knowledge, the six-yearolds would be ready to start their schooling, then due to their behaviour and ability to focusing on, absolutely not". She is convinced that the education programme and standard will have to be changed, as well as longer breaks will have to be provided between the lessons. The six-year-old children lack "selfservice skills for going to the toilet, for fastening up the shoe-laces, for putting on their clothes, for wiping clean their mouths - sometimes even the seven-yearold is not quite sure of such a skill being acquired properly. He/she finds it too difficult to sit for 40 minutes without his/her mom, or a preschool teacher, who gives him/her a hug now and then. There is nothing of that kind at school," says Abelite-Goluba.

The interviewed pedagogy doctor Anna Liduma, who has researched the child development at the preschool age for a long time, is definitely convinced that the natural child development tempo cannot be essentially accelerated. That is established by the researches of neurobiologists as well, who have come to the conclusion that it is impossible to predict when precisely and which brain centres get more mature in the child, and the process cannot be accelerated.

"The child's body has grown more mature at the age of seven years, so then it is possible for the child to endure a seated position at lessons. Definitely, the child has matured adequately both physically and psychically and also socially to commence education at school at the age of seven years. But it is impossible for everyone at the age of six,” explained A. Liduma (Bērtule \& LTV Panorāma, 2016). 
The parents are also worried by the question, who will take care of the sixyear-olds attending Form 1 after the end of the lessons, as the pro-longed day classes are not accessible at every school. It has to be resolved at the state level.

The experienced preschool pedagogue Livija Balcune, who during her long years of work has experienced several attempts to change the existing system, advises - if children have to commence schooling at the age of six years, then better do not send the kindergarteners to school, but transfer Form 1 to the kindergarten. Precisely such an experience the preschool education institutions had already experienced in the school year of 1985/1986, when the previous attempt to commence education at the age of six years was endeavoured. The child really learns much in such benevolent environment, therefore, the education content has to be changed in the way appropriate for the child. The child will have the afternoon nap too, will be taken care of and the parents will have no problems. "Can we with a clear conscience say that we think about the health of our children, not about our half-raised economy?" asks Balcune (Bērtule \& LTV Panorāma, 2016).

The education minister K. Shadurskis is convinced that up to the year of 2018, Form 1 programme can be shaped according to the six-year-olds' abilities and needs. Just now, at this moment the work on the new education standard for all age groups is going on, therefore, it is possible to introduce into it the necessary changes. The minister of education is convinced that the teachers will have to learn much anew, and that is another concern for the ministry, as any reform in education, in its content, is much easily accepted by those undergoing education (meaning: pupils), not by the educators (meaning: teachers). The minister stresses that out of 28 European Union countries in 21 education is commenced at the age of six years or even at the age of five years and somewhere even still earlier, while the children start attending school at the age of seven years in Latvia, Lithuania, Estonia, Bulgaria and Croatia, Finland and Sweden (Bērtule \& LTV Panorāma, 2016).

Yet the education minister gives a promise that the parents, nevertheless, will have a choice whether to send the child to school at the age of six or at the age of seven years, but there will no longer be a possibility to start attending school only at the age of eight. A transition period is also envisaged, as at the present moment the school net is not ready to take in so many, so young first year pupils (Bērtule \& LTV Panorāma, 2016).

As a representative of Latvian Preschool Music Education Association Board, the author guided an experience exchange group of the preschool teachers visiting Warsaw in 2016. During the discussion with the Head of the host kindergarten in Warsaw they found out that the carried out reforms about enrolling of the six-year-old pupils into school attending had suffered a failure 
there. Therefore, the issue that school has to be commenced at the age of 7 is under reconsideration there.

While working in the framework of Erasmus+ project in Hungary in the summer of 2017 together with three colleagues from an Estonian kindergarten, it has been found out that the children start school at the age of seven years in Hungary. The traditions of Hungarian state are respected there and at preschool the children are brought up according to their traditions (the national principle is observed in pedagogy, no one can eliminate it) and they learn their national culture values. So the children's comprehension of identity, citizenship and national values is enhanced due to modelling their teachers' personal example.

In October of 2017 the experience was gained that the children are being prepared for school by competent teachers in Estonia. The purposeful integrated learning sessions are organized by the preschool teachers, whereas the music sessions are conducted by a professional musician.

In October of 2017 in Prague during an experience exchange visit of the preschool teachers, there was an opportunity to compare a professional Music teacher's music-session with another teacher's work-session, who had no music education, therefore, it turned out to be a kind of a musical activity with children. Any further comments would be not appropriate for inclusion into a scientific article.

The observations at Montessori kindergarten in the city of Kladno, involving an under moderate number of children, has caused reflection that in Latvia in children should be promoted the skill of free choice, autonomous action, responsibility for the accomplished and self-assessment of their performance (to compare the expected with the result gained). All the children had been participating with a great interest there.

The author has explored preschool work management in Sweden, Turkey (2x), Australia (in 3 kindergartens), Lithuania, Byelorussia (Minsk), Portuguese Republic, Italy (exceptional collaboration of the local municipality, teachers, parents and children), the United Kingdom, Spain (2x) (the kindergarten is the lowest stage at school there), Iceland (the parents, without being present at the kindergarten, are responsible for their child's actions at the kindergarten). In 2012 in Iceland, the head of a kindergarten to the question, why the teachers were not with children outside during their walk and were not having activities together, gave an answer that so the children were having their autonomous activity, and the parents were responsible for its quality. Moreover, if a child falls ill after being at the kindergarten, the parents are responsible, as they had not provided the child with an appropriate outfit.

In 2012 the experience gained at the Comenius project provided a possibility to draw a conclusion that the preschool teachers of other states 
particularly appreciated national - folk upbringing traditions of Latvia (Liduma, 2015).

The worldwide famous Latvian organist Iveta Apkalna assesses the culture of Latvian music education as follows: "In Berlin I miss Latvian music schools. I can admit that in Latvia the education system existing in our music schools and their input into the further development of the children are under-valued. In Germany the music schools are at the amateur performance level” (Blaua, 2017).

Thanks to the empirical research the opinions of 10 mothers have been received about their now adult children's adventures due to commencing school at the age of six. At the very beginning everything seemed quite normal. They had to devote much time and effort to work with children at home, as their perception of and comprehension on matters, conceptions, phenomena differed from the learning tempo of the 7-year-old pupils. The verbal instructions given by the teachers often were above the comprehension of the pupils younger one year than their classmates, too. The real hardships began in Form 5, when they encountered the subject teachers and had to move from one classroom into another with the heavy school-bags. The education content caused great difficulties to perception. Therefore, guided by this experience, their grandchildren will start school at the age of seven years.

10 deputy heads in education work of the preschool education institutions consider that the children at the age of 6 are ready neither physically, nor psychically, nor socially prepared for education at school.

Among 480 students answering to the questions for and against 6-year-olds education at school, only a minor part (20 students) considers that it is more useful to commence attending school at the age of 6 years. The majority involving 460 students believe that education at school must be commenced at the age of 7 years.

The students' (who are not parents themselves) arguments for the education commencement at the age of six years are the following: it is considered that nowadays children are more developed; the minister of education statements that the education period is too extended (till the age of 19 at school); if the child can orientate at school, is healthy, with a developed vocabulary, is a leader, perceives fast, has an adequate self-assessment.

The students arguments against the education commencement at the age of six years are the following: firstly - subjective conditions: a) the child's personality: b) different physical status (difficult to sit at the desk, need for activity exchange, longer breaks, being outside in fresh air, eating habits); c) psychic status (different communication and collaboration skills, volition problems, level of preparedness, ability for focusing on work, emotional strain; 
d) social development: lack of self-control skills, different cognitive processes, self-service skills (dexterity at putting on clothes, manage to go to the toilet, manage to eat during a break). Psychologically: the child is not ready to time planning, to introducing fast changes yet. Secondly - objective conditions: a) material provision; parents are preoccupied at work, limited time for being occupied with the child; b) the schools are not ready to work physically with 6-year-old children, deficiency of resources, deficiency of rooms, deficiency of technologies. Children have not appropriately adapted to the school demands. The teacher performance style often is authoritarian (forcing to do and obey the teacher). 10 respondents have pointed out that mandatory school commencement at the age of 6 cannot be supported, as the child finds itself in a fast progress at the age of 6-7. Girls have faster development than boys, therefore, especially the boys can endure particular problems caused by this forced earlier school commencement.

There are separate examples that the talented children possessing especially fast perception must be provided with opportunity to commence education at school earlier, provided an opportunity to skip over some year to level up. Another answer reveals: “... there are two sons of age 13 and 17 in the family. The eldest was very fast at the kindergarten age at learning the English, Russian languages and started to learn the German language. In the first years at school he was interested in the exact subjects, which are being taught in later years, was reading much in adapted for junior age encyclopedias and scientific literature, attended various educative societies. He was bored at school. It was observed by the teachers, and at the end of Form 3 he was promoted to Form 5, where he was doing well. While learning at the prestigious grammar school in the international integrated baccalaureate programme, the learner of Form 8 attends various societies and has definite future career plans. The other child has a different experience. The communication is adequate to its age, but the cognitive development is lagging behind. He watches cartoons in the English language, but mixes up the Latvian and English languages, finds difficulties in focusing on and retaining attention. It has been caused by the mother's unfavourable psychological condition during pregnancy.

5 respondents stress that hustle with 6-year-old children education at school has been artificially caused in order to turn attention off other acute issues in education.

And finally, the personal experience of the author of the article is based on commencement of education at school at the age of six and a half (6 years 6 months). The parents were teachers, father was also the head of school. Due to living close to the school building, there was an early experience of being in the school, listening to the parents, how good it is when one is smart, how interesting it is. At the conscientious age all stages of cognitive interests 
development had been enjoyed: curiosity, inquisitiveness, cognitive interest (thirst for knowledge), which developed into a theoretical interest in Form 8 due to a practical need (due to preparing for the Latvian language examination, the father was asked to explain, how it can be done). He answered that he had no idea how. Each does it differently. Nothing doing: she learned herself and searched the method how to learn autonomously. It was found and its promotion was continued during the rest of life stages. But the father's answer had been understood to the core, when she had shared it with her brother in 2017, because the brother's positive assessment of the father's answer revealed what exactly had stimulated the development to autonomous choice, self-dependence, independence and responsibility in her teenage years. But nowadays it is the exact aim of the upbringing in Latvia. It is very important to promote in children autonomous choice, need for success achievement and collaboration (these are the principles of upbringing in pedagogy formulated by A. Spona in 2014.)

In assessment: 1) in Latvian pedagogy significant are the concepts included in the Pedagogical letters by the outstanding music pedagogue Julius Rozitis (1934) that "important are your own state's upbringing interests (do not search highway hedge-grows in distant countries, but look into the yard of your own home) in the first half of the $20^{\text {th }}$ century" (Liduma, 2004: 51-52), 2) A. Spona's concepts of the upbringing principles in the $21^{\text {st }}$ century (2014), 3) the concepts on citizenship, upbringing/self-upbringing values gained by the author of the article due to her 70 scientific articles written, researches for 3 monographs accomplished, the author finds of the utmost actuality Janina Kursite's conception (1996): "The culture without sustainability in traditions inherited is a one day phenomenon, as it is devoid of both the past and the future alike. The past is eliminated by itself, but the future will also eliminate itself in due time, if the present possesses the destructive model instead of the creative model" (Līduma, 2013: 26).

Assessing the ongoing contemporary processes, many important and pending matters are spotlighted, which we should resolve in contemporary conditions. It is important not to destroy the pedagogical process in Latvia's school, but:

1. Consider, how to involve into school those 17803 children - pupils enrolled in no school at all (Ziņu aǵentūra LETA, 17. janvāris).

2. Develop improvements to the pedagogical process on the existing well-developed basis.

3. Create a coordinated collaboration of the teacher - parents, so that the child is provided with support, not injured in fights on redistribution of responsibilities. 
4. Purposefully and gradually to promote development of all potential abilities and cognitive interests of the child.

5. Balance the objective (principles, instrumentation of implementation: content, methods and forms) and the subjective (child personality's development) components of the pedagogical process in order to sparkle up interest in the children for self-dependent action.

6. Actuate the transition from the authoritarian leadership style (to give assessment, to let accomplish action, to push to do etc.) to the democratic teacher performance style (which is set at the basis of the innovative competence approach: to open up opportunities; to ensure conditions, challenge self-upbringing, to self-assess).

7. To use democratic language (foster, facilitate, provide an opportunity, it is important, needed, should ...) and eliminate the regulation of each human action by orders, instead provide with opportunities to develop self-regulatory attitudes.

8. For the teacher to provide conditions and the material basis at each workstation, to engage by guidance, for the teacher to challenge a consultant and collaboration partner position (attitude to the child during accomplishing an action together), to function as a friend, helper, support-provider during a self-assessment-assessment and collaboration action.

9. To pay to the teacher an adequate salary for the work done.

\section{Conclusion}

The accomplished research has determined the formulation of the final concepts:

Elimination of the authoritarian approach to the teacher's profession has to be accomplished. The transition to the democratic approach to learners has to be implemented, so that the teacher can develop a democratic teacher's work style, balance the requirements with the actual needs for the child development, balance the objective and the subjective components of the pedagogical process at preschool. It demands to promote to perfection the technical equipment of each preschool teacher.

Transforming education of the Latvian state, introduce the useful Finland's experience, which determines that the child matures for the education at school at the age 6 to 7 years. The fast acceleration at operation in the central nervous system and the brain occurs in 7-year-old children at school, moreover, it is different and individual for each child.

The pedagogical process for the children at the ages of 6-7years gradually have to reach approximation to the school pedagogical process, developing the 
Liduma, 2018. Scientific Substantiation: for and Against 6-Year-Old Children Commencing School Education

play-session so that it enhances the children cognitive interests and the children themselves promote their adaption to school, successively and naturally integrating themselves.

For assessment of achievements to use the model: self-assessmentassessment, maximizing on their reciprocal connection and balance.

The pedagogical process has to be in compliance with the requirements of the Latvian state and has to be based on the concepts of the scientists of Latvia for all age groups: preschool, basic school, secondary school and adult further education on self-experience empowering through the self-upbringing process. The preschool age is of exceptional significance.

\section{References}

Bērtule, A., \& LTV Panorāma. Sešgadnieks skolā - ierēdṇu un speciālistu viedokḷ atškiriras. 27. augusts. 2016. 21:07. Retrieved from http://www.lsm.lv/raksts/zinas/latvija/ sesgadnieks-skola-ierednu-un-specialistu-viedokli-atskiras.a198221/

Blaua, L. (2017). Ērgéẹ̣ pavēlniece. Personisks stāsts. Ievas stāsti. 2017. 22.12.-2018.05.01. Nr. 26 (338) 2017. 4. - 8.

Gardner, H. (2007). Five Minds for Future. Harvard Business, Boston, MA. 195 p. Retrieved from http://www.amazon.com/gp/reader/1591399122/ref=sib_dp_srch_pop?v= search inside\&keywords $=$ References\&go. $\mathrm{x}=12 \& \mathrm{go} . \mathrm{y}=9 \mathrm{~g} \mathrm{go}=\mathrm{Go} \% 21 \#$

Geidžs, N. L., \& Berliners, D. C. (1999). Pedagogiiskā psihologiija. Rīga: Zvaigzne ABC.

Greata, J. (2006). An Introduction to Music in Early Childhood Education. Australia, Mexico, Singapore, Spain, United Kingdom, United States: Thomson Delmar Learning.

Hibnere, V. (1998). Bērna vizuālā darbība. Rīga: Raka.

Introduction of kindergarten Vardarvacka. Materials of Erasmus+ project. 2017. 20 p.

Kuzmina, I. (2017). Nekad agrāk izglîtīiāa nav bijis tik daudz pārmainuu. Intervija ar Somijas Valsts izglīî̄ibas aǵentūras mācību satura emeritēto vadītāju Irmeli Halinenu. Latvijas Avīze. 2017. otrdien, 3. oktobris, 5.

Līduma, A. (2004). Jūlijs Rozīitis. Dzīve un darbība. Rēzekne: LKCI.

Līduma, A. (2013). Bērna līdzsvarotas attīstības pedagoǵiski psihologiskie nosacījumi pirmsskolā. Pirmsskolas pedagoǵijas teorija praksei (118.-127. lpp.). Rīga: Librum.

Līduma, A. (2014a). Bērna attīstības iespējas pirmsskolas izglìtības Pedagoğiskajā procesā. The collection of scientific papers 2014, 33-45

Liduma, A. (2014b). Pedagogical psychological correlations of potentials and abilities. Proceeding of the International Scientific Conference Society. Integration. Education, May $23^{\text {th }}-24^{\text {th }}, 2014$, Vol. I, 570-580.

Liduma, A. (2015). Intercultural competence development in Comenius project "Me and my Europe: intercultural challenges of modern pre-primary education" participants at preprimary education. Proceedings of the International Scientific Conference May $22^{\text {th }}$ $23^{\text {th }}$, 2015, Vol. II. Retrieved from http://journals.ru.lv/index.php/SIE/article/view/432

Liduma, A. (2017). Collaboration in the kindergarten as a pedagogical means for developing positive attitudes. International dialogues on education: Past and Present. IDE. Online Journal. 2017, Volume 4, Number 1. Retrieved from http://www.idejournal.org/journal/?issue= 2017-volume-4-number-1 
Noteikumi par Valsts pirmsskolas izglītības vadlīnijām - Likumi.lv. 2012. Retrieved from https://likumi.lv/doc.php?id=250854

Pirmsskolas Izglītības mācību satura programma. (2012). Atbildīgā par izdevumu Agrita Miesniece. Retrieved from: http://visc.gov.lv/vispizglitiba/saturs/dokumenti/ programmas/pirmsskolai/pirmssk_izgl_mac_programma.pdf

Project Erasmus+ Me and Music. No 2016-1-LV01-KA201-022696

Projekts. Izglītība mūsdienīgai lietpratībai: mācību satura un pieejas apraksts. Retrieved from www.skola2030.lv

Randoha, A. (2015). Development of Pre-school children's visual capacities in fine arts. Summary of Ph.D. Dissertation. Riga: RTTEMA.

Stangaine, I. (2014). Development of dialogue speech of pre-school age child in play Summary of Ph.D. Dissertation. Riga: RTTEMA.

Špona, A. (2006). Audzināšanas process teorijā un praksē. Rīga: Raka.

Veugelers, W, de Grot, I., \& Stolk, V. (2017). Research for CULT Comittee - Teaching Common Values in Europe. European Parliament. Policy Department for Structural and Cohesion Policies, Brussels. Retrieved from http://www.europarl.europa.eu/ RegData/etudes/STUD/2017/585918/IPOL_STU(2017) 585918_EN.pdf

Vigule, D. Development of a Pre-schooler's Will Characteristics through Actions with Toys Summary of Ph.D. Dissertation. Riga: RTTEMA.

Vispārējās izglītības likums. 20. pants. Pirmsskolas izglītības programma. (1999). Retrieved from https://likumi.lv/ta/id/20243-visparejas-izglitibas-likums/redakcijas-datums/1999/ $08 / 13$

Wulf. Ch. (2007). Antropologie. Geschochte, Kultur, Philosophie. Reinbek bei Hamburg. Beltz Lexikon Pädagogik. S. 542-545

Ziņu ağentūra LETA, 17.janvāris. (2018). Šogad skolās nav registrēti gandrīz 18000 Latvijas bērnu. Retrieved from http://nra.lv/latvija/izglitiba-karjera/234525-šogad-skolas-navregistreti-gandriz-18000-latvijas-bernu.htm

Выготский, Л. С. (1997). Вопросы детской психологии. Санкт-Петербург: Союз.

Крайг, Г., \& Бокум, Д. (2004). Психология развития. Санкт-Петербург: Питер.

Психология детства. (2006). Под ред. А.А. Реана. Часть 1. (с. 11-90). Санкт-Петербург: Прайм-ЕВРОЗНАК.

Эльконин, Д. Б. (1989). Избранные психологические труды. Москва: Педагогика.. 